\title{
PEMBELAJARAN PENDIDIKAN AGAMA ISLAM BAGI ANAK BERKEBUTUHAN KHUSUS DI SEKOLAH INKLUSI
}

\author{
Farida Isroani \\ STITMA Tuban, Indonesia \\ isroanifarida@gmail.com
}

\begin{abstract}
Abstrak
Penelitian ini bertujuan untuk mengetahui manajemen pembelajaran PAI di sekolah Inklusi. Dalam penelitian ini penulis menganalisis data dengan teknik analisa kualitatif. Temuan dalam penelitian ini ada empat antara lain (1) perencanaan pembelajaran PAI bagi ABK dalam settingan inklusi (2) pelaksanaan pembelajaran PAI yang beragam strategi (3) Evaluasi hasil pemeblajaran PAI(4) Kendala yang dihadapi baik dalam perencanaan, pelaksanaan dan evaluasi pembelajaran PAI di sekolah inklusi.
\end{abstract}

Keyword : manajemen, pembelajaran PAI, $A B K$

\begin{abstract}
This study aims to determine the management of PAI learning in the Inclusion school. In this study the authors analyzed the data with qualitative analysis techniques. The findings in this study are four, among others (1) PAI learning planning for ABK in inclusion settings (2) implementation of PAI learning with various strategies (3) Evaluation of PAI learning outcomes (4) Constraints faced both in planning, implementing and evaluating PAI learning in inclusive schools.
\end{abstract}

Keyword: management, learning PAI, $A B K$

\section{A. Pendahuluan}

Berdasarkan UU Sisdiknas No. 20 tahun 2003 dalam pasal 5 ayat 2 juga menyebutkan bahwa "setiap warga negara memiliki kelainan fisik, mental, sosial, intelektual dan atau sosial berhak memperoleh pendidikan khusus. Dengan kata lain, perkembangan manusia ada yang wajar atau normal dan ada yang perkembangannya terganggu (abnormal) yang akan berpengaruh terhadap mental dan dan jasmani. Sehingga dalam permasalahan pendidikan, tidak ada perbedaan antara anak yang normal perkembangan jasmani dan rohaninya, dengan anak anak yang mengalami kecacatan fisik atau kelemahan mental yang sering disebut sebagai anak berkebutuhan khusus. 
Anak berkebutuhan khusus (ABK) dapat dimaknai dengan anak-anak yang tergolong cacat atau yang menyandang ketunaan, dan juga anak lantib dan berbakat.Dalam perkembangannya, saat ini konsep ketunaan berubah menjadi berkelainan (exception) atau luar biasa. Konsep ketunaan berbeda dengan konsep berkelainan.Konsep ketunaan hanya berkenaan dengan kecacatan, sedangkan konsep bekelainan atau luar biasa mencakup anak yang menyandang ketunaan maupun yang dikaruniai keunggulan.

Beberapa yang termasuk kedalam anak berkebutuhan khusus antara lain: tunanetra, tunarungu, tunagrahita, tunadaksa, tunalaras, kesulitan belajar, gangguan prilaku, anak berbakat, dan anak dengan gangguan kesehatan. Anak berkebutuhan khusus memerlukan bentuk pelayanan pendidikan khusus yang disesuaikan dengan kemampuan dan potensi mereka, contohnya bagi tunanetra mereka memerlukan modifikasi teks bacaan menjadi tulisan Braille dan tunarungu berkomunikasi menggunakan bahasa isyarat.

Pendidikan agama Islam merupakan usaha sadar dan terencana untuk menyiapkan siswa dalam meyakini, memahami, manghayati dan mengamalkan ajaran Islam melalui kegiatan bimbingan, pengajaran dan latihan. Pendidikan, khususnya pendidikan agama Islam tidak hanya diberikan kepada anak yang mempunyai kelengkapan fisik saja, akan tetapi juga diberikan kepada anak yang mempunyai kelainan dan kekurangan fisik atau mental. Peserta didik dipandang sebagai makhluk Tuhan dengan fitrah yang dimiliki, sebagai makhluk individu dan makhluk sosial. Setiap peserta didik memiliki perbedaan minat, kemampuan, kesenangan, pengalaman dan cara belajar.

Rachmita menyebutkan bahwa salah satu permasalahan di Indonesia adalah kurangnya pemahaman, kesadaran, dan akses terhadap hak asasi manusia yang megakibatkan ketidakmampuan anak-anak berkebutuhan khusus dalam berpartisipasi secara utuh dalam kehidupan masyarakat (Rachmita M.Harahap 2008 : xi). Pendidikan adalah hal yang mendasar bagi manusia. Untuk mencapai proses pemenuhan hak dasar dalam bidang pendidikan diperlukan strategi pemerataan pendidikan yang berkualitas sehingga hak semua ank dalam bidang 
pendidikan dapat dipenuhi dan pendidikan untuk semua (Education For All/EFA). Namun disini, perlu disadari bahwa layanan pendidikan, utamanya dalam pembelajaran bagi anak berkebutuhan khusus tentu beda dengan anak normal. Oleh karena itu perlu adanya solusi dalam manajemen pembelajaran Pendidikan Agama Islam di sekolah inklusi.

\section{B. Pembahasan}

\section{Pembelajaran PAI}

Pembelajaran adalah proses aktif siswa untuk mempelajari dan memahami konsep yang dikembangkan dalam kegiatan belajar mengajar. Proses belajar mengajar, merupakan proses interaksi komunikasi aktif antara siswa dengan guru dalam kegiatan pendidikan. Dalam kegiatan belajar mengajar ada kegiatan yang dilakukan siswa dan ada kegiatan yang dilakukan guru yang terjadi secara sinergis. Proses pembelajaran harus diupayakan dan selalu terikat dengan tujuan. Oleh karenanya, segala interaksi, metode dan kondisi pembelajaran harus direncanakan dan mengacu pada tujuan pembelajaran yang dikehendaki.

Agama memiliki peran yang amat penting dalam kehidupan umat manusia.Agama menjadi pemandu dalam upaya untuk mewujudkan suatu kehidupan yang bermakna, damai dan bermartabat.Menyadari bahwa peran agama amat penting bagi kehidupan umat manusia, maka internalisasi agama dalam kehidupan setiap pribadi menjadi sebuah keniscayaan, yang ditempuh melalui pendidikan baik pendidikan di lingkungan keluarga, sekolah maupun masyarakat.

Pendidikan Agama Islam (PAI) merupakan usaha sadar dan terencana untuk menyiapkan siswa dalam meyakini, menghayati dan mengamalkan ajaran Islam melalui kegiatan bimbingan, pengajaran dan latihan. Pendidikan Agama Islam yang pada hakikatnya merupakan sebuah proses itu, dalam pengembangannya juga dimaksudkan sebagai rumpun mata pelajaran yang diajarkan di sekolah maupun perguruan tinggi. 
Dalam pembelajaran PAI harus didasarkan pada pengetahuan siswa yang belajar dan lebih sering dikaitkan pada suatu materi mata pelajaran lain. Pembelajaran PAI ini juga harus menjadi sesuatu yang direncanakan dari pada hanya sekedar asal jadi. Pengertian pembelajaran PAI adalah proses pendidikan yang diselenggarakan untuk mempelajari Agama Islam secara benar-benar sehingga Agama tidak hanya sebagi pengetahuan saja, melainkan sebagai pengalaman dan pedoman hidup seseorang.

\section{Tujuan Pembelajaran PAI}

a. Menumbuhkembangkan aqidah melalui pemberian, pemupukan, dan pengembangan pengetahuan, penghayatan, pengamalan, pembiasaan, serta pengalaman peserta didik tentang agama Islam sehingga menjadi manusia muslim yang terus berkembang keimanan dan ketakwaan kepada Allah SWT.

b. Mewujudkan manusia Indonesia berakhlak mulia yaitu manusia yang produktif, jujur, adil, etis, berdisiplin, bertoleransi (tasammuh) serta menjaga hamoni serta personal dan sosial.

Jadi, tujuan pembelajaran PAI disini akan mampu memprediksikan kebutuhan-kebutuhan dan kesiapan pendidikan Agama Islam dalam menyiapkan sumber daya yang diperlukan selaras dengan kebutuhan siswa, orang tua, maupun masyarakat.

\section{Ruang Lingkup dan Bahan Pembelajaran PAI}

Ruang lingkup pendidkan agama Islam meliputi keserasian, keselarasan dan keseimbangan antara:

a. Hubungan manusia dengan Allah SWT

b. Hubungan manusia dengan sesama manusia

c. Hubungan manusia dengan dirinya sendiri

d. Hubungan manusia dengan mahluk lain dan lingkungannya.

Adapun ruang lingkup bahan pelajaran pendidikan agama Islam meliputi lima unsur pokok yaitu: Al-Qur'an, Aqidah, Syari'ah, Akhlak, dan Tarikh (sejarah). Pada Pendidikan Inklusi penekanan diberikan pada tiga hal yaitu: 
a. Kepercayaan (i'tiqadiyah), yang berhubungan dengan rukun iman,

b. Perbuatan ('amaliyah), yang terbagi dalam dua bagian:

(1) masalah Ibadah, berkaitan dengan rukun Islam, seperti syahadat, shalat, zakat, puasa, haji, dan ibadah-ibadah lain yang mengatur hubungan manusia dengan Allah SWT.; (2) masalah Mu'amalah, berkaitan dengan interaksi manusia dengan sesamanya,

c. Etika (khulukiyah), berkaitan dengan kesusilaan, budi pekerti, adab atau sopan santun yang menjadi perhiasan bagi seseorang. Materi merupakan komponen kedua dalam sistem pembelajaran. Dalam konteks tertentu, materi merupakan inti dalam proses pembelajaran. Artinya, sering terjadi proses pembelajaran diartikan sebagai proses penyampaian materi.

\section{Metode Pembelajaran PAI}

Metode adalah komponen yang juga mempunyai fungsi yang sangat menentukan. Bagaimanapun lengkap dan jelasnya komponen lain, tanpa dapat diimplementasikan melalui metode yang tepat, maka komponen-komponen tersebut tidak akan memiliki makna dalam proses pencapaian tujuan. Oleh karena itu setiap guru perlu memahami secara baik peran dan fungsi metode dalam pelaksanaan proses pembelajaran. Dari uraian tentang metode tersebut dapat dipahami bahwa penerapan metode dapat dijadikan sebagai motivasi dalam proses pembelajaran sekaligus sebagai alat pencapaian tujuan.

Menurut al-Nahlawi dalam Ahmad Tafsir, metode untuk menanamkan rasa iman antara lain:
a. Metode hiwar (percakapan) Qurani dan Nabawi
b. Metode kisah Qurani dan Nabawi
c. Metode Amtsal (perumpamaan) Qurani dan Nabawi
d. Metode keteladanan
e. Metode pembiasaan
f. Metode 'Ibrah dan mauizah (nasihat) 
g. Metode targhib (menceritaan hal yang menyenangkan) dan tahrib (cerita ancaman berbuat dosa dll).(Ahmad Tafsir, 2005:135)

\section{Fungsi Pembelajaran PAI}

Pendidikan Agama Islam di sekolah berfungsi sebagai berikut:

a. Pengembangan, yaitu meningkatkan keimanan dan ketaqwaan siswa kepada Allah SWT yang telah ditanamkan dalam lingkungan keluarga. Pada dasarnya pertama-pertama kewajiban menanamkan keimanan dan ketaqwaan dilakukan oleh setiap orang tua dalam keluarga.

b. Penyaluran, yaitu untuk menyalurkan siswa yang memiliki bakat khusus di bidang agama agar bakat tersebut dapat berkembang secara optimal sehingga dapat dimanfaatkan untuk dirinya sendiri dan dapat pula bermanfaat bagi orang lain.

c. Perbaikan, yaitu untuk memperbaiki kesalahan-kesalahan, kekurangankekurangan, dan kelemahan-kelemahan siswa dalam keyakinan, pemahaman dan pengalaman ajaran Islam dalam kehidupan sehari-hari.

d. Pencegahan, yaitu untuk menangkal hal-hal negatif dari lingkungannya atau dari budaya asing yang dapat membahayakan dan menghambat perkembangan dirinya menuju manusia Indonesia seutuhnya.

e. Penyesuaian, yaitu untuk menyesuaikan diri dengan lingkungannya, baik lingkungan fisik maupun lingkungan sosial dan dapat mengubah lingkungannya sesuai dengan ajaran Islam.

f. Sumber nilai, yaitu untuk memberikan pedoman hidup untuk mencapai kebahagiaan hidup di dunia dan akhirat.

\section{Anak Berkebutuhan Khusus}

\section{a. Pengertian anak berkebutuhan khusus}

Anak berkebutuhan khusus merupakan sebutan pengganti dari anak luar biasa. Sebutan anak berkebutuhan khusus (children with special needs) merupakan sebutan yang lebih sopan daripada anak cacat ( Ekodjatmiko Sukarso, dkk 2001:5). Anak berkebutahan khusus didefiniskan sebagai anak-anak yang berbeda dari anak-anak yang biasa dalam hal ciri-ciri 
mental, kemampuan sensorik, kemampuan komunikasi , tingkahlaku social, ataupun ciri-ciri fisik (Jamila K.A.Muhammad, 2008:37).

Anak berkebutuhan khusus adalah anak dengan karakteristik khusus yang berbeda dengan anak pada umumnya, tanpa selalu menunjukkan pada ketidak mampuan mental, emosi atau fisik. Yang termasuk ke dalam ABK antara lain: tunanetra, tunarungu, tunagrahita, tunadaksa, tunalaras, kesulitan belajar, gangguan prilaku, anak berbakat, anak dengan gangguan kesehatan. Istilah lain bagi anak berkebutuhan khusus adalah anak luar biasa dan anak cacat. Karena karakteristik dan hambatan yang dimiliki, ABK memerlukan bentuk pelayanan pendidikan khusus yang disesuaikan dengan kemampuan dan potensi mereka, contohnya bagi tunanetra mereka memerlukan modifikasi teks bacaan menjadi tulisan braille dan tunarungu berkomunikasi menggunakan bahasa isyarat.

Pelaksanaan pendidikan bagi anak berkebutuhan dapat dilakukan dengan dua model, yaitu :

1) Secara tersendiri / khusus (segresi) artinya anak berkebutuhan khusus dikelompokkan dengan sesamanya.

2) Secara terpadu (inklusi) artinya anak berkebutuhan khusus dikelompokkan dengan anak pada umumnya dalam satuan pendidikan, tentunya dibantu oleh guru pembimbing/ tenaga ahli pendidikan luar biasa (Ekodjatmiko Sukarso dkk, 2001:18).

Secara umum penyelenggaraan pendidikan bagi anak berkebutuhan khusus agar mandiri mengacu pada dua prinsip pokok, yaitu:

1) Rehabilitasi, yaitu mengupayakan untuk memperbaiki kekurangan dalam taraf tertentu.

2) Habilitasi, yaitu upaya penyadaran bahwa dirinya masih memiliki kemampuan yang dapat diberdayakan (Ekodjatmiko Sukarso dkk, 2001:25). 


\section{b. Karakteristik anak berkebutuhan khusus}

Anak berkebutuhan khusus yang paling banyak mendapat perhatian guru menurut Kauffman dan Hallahan (Kauffman dan Hallahan, 2005 : 28-

45) adalah sebagai berikut :

1) Tunagrahita disebut sebagai anak dengan anak dengan keterbatasan perkembangan

2) Kesulitan Belajar atau anak yang berprestasi rendah

3) Hiperaktif

4) Tunalaras

5) Tunarungu wicara

6) Tunantera

7) Anak autis

8) Tunadaksa

9) Anak berbakat

\section{c. Prinsip-prinsip pembelajaran anak berkebutuhan khusus}

Adanya suatu kegiatan pembelajaran yang dilaksanakan adalah untuk mencapai sebuah tujuan secara efektif dan efesien.Dalam hal tersebut, seorang guru seharusnya memperhatikan prinsip-prinsipdi kelas inklusif secara umum. Di dalam kelas inklusif terdapat anak-anak yang memiliki kebutuhan yang berbeda, yaitu anak-anak yang memiliki kelainan atau penyimpangan, baik berupa fisik maupaun intelektual, sosial, emosional, atau sensorik neurologis dibandingkan dengan anak-anak pada umumnya dan mengemplementasikan prinsip-prinsip khusus sesuai dengan kelainan anak;

1) Prinsip motivasi

Guru harus senantiasa memberikan motivasi kepada anak agar tetap memiliki gairah dan semangat yang tinggi dalam mengikuti kegiatan belajar mengajar. Oleh karena itu, dalam pemberian motivasi harus lebih sering guru lakukan secara personal antara anak yang satu 
dan anak yang lainnya karena masing-masing anak memiliki tingkatan masalah yang berbeda.

2) Prinsip latar/ konteks

Adanya sebuah pengenalan antara guru dan muridnya tentu saja akan sangat berarti. Hal ini perlu dilakukan dan dipertahankan demi sebuah kelancaran dalam sebuah proses pencarian jati diri anak tersebut. Yang secara tidak langsung perlu adanya orang-orang yang bersedia mengerti dan memahami kondisinya serta dalam proses pendidikan karena hal ini bisa menjadi salah satu peran yang tidak kalah pentingnya. Dengan adanya kedekatan antara guru dan muridnya, tentu saja hal ini akan membantu dalam pengenalan seberapa besar kemampuan anak

Tentu saja dengan pengetahuan latar tersebut dapat membantu guru untuk mengetahui anak tersebut masuk kedalam kategori yang ringan, sedang, atau berat.Dengan demikian, guru dapat memberikan materi pembelajaran kepada murid-muridnya sesuai dengan porsi anak tersebut.

Guru perlu mengenal anak didiknya secara mendalam dengan memberikan contoh secara langsung, dapat untuk memanfaatkan sumber belajar yang ada dilingkungan sekitar secara tepat dan semaksimal mungkin, juga menghindari pengulangan-pengulangan materi pengajaran yang sebenarnya tidak perlu terlalu penuh untuk ABK mengingat latar mental dan fisik anak tersebut.

3) Prinsip keterarahan

Pada prinsip ini, setiap anak yang mengikuti kegiatan secara mendalam, guru harus merumuskan secara matang tujuan kegiatan tersebut secara jelas.Yang tentunya tujuan tersebut baik untuk anak didiknya. Dalam penerapan suatu bahan dan alat yang sesuai dengan kategori anak yang menjadi murid serta guru, juga harus dapat untuk mengembangkan strategi pembelajaran yang tepat agar sesuai dengan 
porsi muridnya tersebut sehingga justru tidak menimbulkan masalah pada anak tersebut.( Muhammad Effendi: 11)

4) Prinsip hubungan sosial

Dalam sebuah proses belajar mengajar, seorang guru harus dapat mengembangkan setiap strategi pembelajaran yang mampu untuk mengoptimalkan interaksi antara guru dengan muridnya. Hubungan antara murid dan sesama murid, guru dan murid dan lingkungannya, serta interaksi yang berasal dari berbagai arah.

5) Prinsip belajar sambil bekerja

Dalam kegiatan pembelajaran, guru harus banyak memberi kesempatan kepada anak untuk melakukan sendiri praktik atau percobaan atau menemukan sesuatu melalui pengamatan, penelitian dan sebagainya.Dengan demikian, anak tersebut mampu berkembang sendiri. Jangan sampai guru justu membuat muridnya menjadi anak yang tergantung dengan orang lain hanya karena ketidaksempurnaan yang ada dalam dirinya tersebut. Biarkan mereka melakukan sesuatu yang dapat mengembangkan dirinya dan ini sungguh sangat efektif bagi proses pendidikan anak tersebut, termasuk juga untuk melatih anakanak tersebut agar dapat menghadapi dan mengatasi setiap masalah yang mungkin akan sangat sering mereka jumpai.(Meilani Kasim)

6) Prinsip individualisasi

Dalam prinsip ini, guru perlu mengenal kemampuan awal dan karakteristik setiap anak secara mendalam, baik dari segi kemampauan maupun ketidakmampuannya, dalam menyerap materi pelajaran.Kecepatan maupun kelambatannya dalam belajar dan perilakunya sehinga setiap kegiatan pembelajaran masing-masing anak mendapat perhatian dan perlakuan yang sesuai.Dengan demikian, tidak terjadi ketimpangan antara anak yang satu dengan anak yang lainnya. 
7) Prinsip menemukan

Guru perlu mengembangkan strategi pembelajaran yang mampu memancing anak untuk terlihat secara aktif, baik fisik, mental, sosial atau emosionalnya. Untuk itu, peran guru sangat diperlukan di sini untuk mengembangkan strateginya demi membuat anak didiknya menjadi lebih terpancing dan bersemangat untuk belajar, dan mengenal, apa yang guru terangkan kepada mereka.

Dengan demikian, anak-anak tersebut kini tidak lagi merasakan adanya kekurangan dalam dirinya dan membanding-bandingkan dirinya dengan anak-anak normal lain yang ada hanyalah bahwa dirinya kini menjadi seorang yang sama dengan anak normal lainnya, yaitu dirinya mampu belajar dan berhak untuk mendapatkan pengajaran.

8) Prinsip pemecahan masalah

Guru hendaknya sering mengajukan berbagai persoalan yang ada di lingkungan sekitar dan anak dilatih untuk mencari data, menganalisis, dan memecahkan masalah tersebut sesuai dengan kemampuan masing-masing dan guru sebaiknya tidak begitu memaksakan anak tersebut agar tidak menjadikan hal tersebut menjadi sebuah beban.

Dengan prinsip pemecahan masalah tersebut, dapat merangsang anak untuk berpikir keras dan melatih anak tersebut untuk tidak mudah menyerah dalam keadaan apa pun. Hal ini melatih anak tersebut untuk tetap bertahan serta mentalnya pun dapat terlatih dengan baik dalam menghadapi segala permasalahan yang ada dalam kehidupan yang sebenarnya.

\section{d. Metode pembelajaran anak berkebutuhan khusus}

Hal-hal yang perlu diperhatikan oleh kepala sekolah, guru, dan keluarga sehubungan dalam merencanakan pembelajaran PAI unuk Pendidikan Inklusi antara lain: 
1) Tunanetra

Anak tunanetra mengalami kekurangan pada gerak dan mobilitas, perabaan serta penggunaan sisa penglihatan bagi low vision. Untuk mereka pengembangan kegiatan pembelajaran PAI sebenarnya tidak hanya di sekolah saja, akan tetapi perlu dikembangkan juga di lingkungankeluarga dan masyarakat. Adapun pengembangannya adalah sebagai berikut

2) Tunagrahita

Anak tunagrahita kekurangannya terletak pada lemahnya mental atau intelektual.

a) Pengembangan materi

Dalam menyajikan materi keagamaan bagi anak tunagrahita harus lebih disederhanakan dan diturunkan, bobot materinya disesuaikan dengan kemampuan dan kesanggupan anak itu sendiri.

b) Pengembangan metode

Metode pengembangan hendaknya bervariasi.kadang satu materi harus dengan 6 (enam) atau 8 (delapan) metode. Sebab anak tunagrahita lebih sulit dan susah dalam menjalani proses pembelajaran dikarenakan keterbatasannya dalam mental intelegensinya

c) Pengembangan sistem penilaian

Menilai hasil belajar PAI bagi anak tunagrahita hendaknya lebih ditekankan pada aspek efektif dan pisikomotor, karena kemampuan kognitifnya terbatas. Meskipun aspek kognitif harus dinilai, tetapi jangan dijadikan ukuran atau standar pokok dari keberhasilan belajarnya

3) Tunarungu

Kekurangan anak tunarungu atau tunawicara terletak pada pendengaran dan percakapan. 
a) Dalam pengembangan materi PAI bagi anak tunarungu tidak dalam bentuk ceramah sebagaimana anak "awas" (umum) lainya, tetapi dengan cara percakapan. Jadi guru harus lebih aktif dalam percakapan. Apalagi yang menyangkut ibadah dengan mengucapkan lafal atau bacaan.

b) Materi PAI hendaklah disesuaikan dengan kemampuan anak, serta dilakukan pengelompokan sesuai dengan kemampuannya. Anak yang

c) Pandai harus disendirikan dari anak yang berkemampuan sedang atau kurang.

4) Tunadaksa

Kekurangannya paada kerusakan atau hilangnya anggota fisik. Dalam pengembangan materi PAI bagi anak tunadaksa baik dari segi materi maupun metodologi pengajaran hampir sama dengan anak-anak tunanetra dan tunalaras, hanya perlu bimbingan dalam gerakan karena keterbatasan atau kecacatan fisik mereka yang perlu diarahkan, apalagi yang menyangkut gerakan-gerakan ibadah sholat.

5) Tunalaras

Kekurangannya terletak pada pembinaan pribadi dan sosial. Dalam pengembangan materi PAI bagi anak tunalaras materi dan metodologi pengajaran hampir sama dengan anak-anak tunanetra dan tunadaksa. Yang berbeda, guru perlu mengkondisikan dan mengkonsentrasikan anak tersebut dalam praktik ibadah maupun pembelajaran di kelas karena anak tunalaras sangat sulit untuk berkonsentrasi atau terlalu banyak gerakan-gerakan ( DEPAG RI, 2007: 46).

\section{e. Manajemen Pembelajaran PAI Bagi Anak Berkebutuhan Khusus}

Sebagaimana yang telah tertulis pada uraian sebelumnya, bahwa untuk mencapai hasil belajar seperti yang diharapkan, para pendidik perlu merencanakan dan menerapkan strategi pembelajaran terbaik. Keberhasilan 
belajar dan mengajar bergantung pada faktor-faktor pendukung terjadinya pembelajaran yang efisien dan efektif.

Dalam sekolah, khususnya bidang kurikulum atau pembelajaran dibagi dalam tiga tahapan, yaitu rencana pembelajaran, kegiatan atau pelaksanaan pembelajaran dan penilaian hasil belajar.

1) Perencanaan pembelajaran

Perencanaan merupakan fungsi manajemen yang menentukan secara jelas pemilihan pola-pola pengarahan untuk pengambilan keputusan, sehingga terdapat koordinasi dari demikian banyak keputusan dalam kurun waktu tertentu dan mengarah kepada tujuantujuan yang telah ditentukan.

2) Pelaksanaan pembelajaran

Pelaksanaan pembelajaran adalah operasionalisasi dari perencanaan pembelajaran, sehingga tidak lepas dari perencanaan pengajaran atau pembelajaran yang sudah dibuat. Oleh karenanya dalam pelaksanaannya akan sangat tergantung pada bagaimana perencanaan pengajaran sebagai operasionalisasi dari sebuah kurikulum.

3) Evaluasi pembelajaran

Standar kompetensi untuk setiap mata pelajaran pada setiap ketunaan berbeda, sesuai dengan karakteristik ketunaan yang dimiliki oleh setiap peserta didik.Hal penting yang harus adalah ciri pembelajaran dan penilaian pada pendidikan khusus dengan memperhatikan karakteristik; kemampuan; keterbatasan baik secara emosional, intelektual, fisikal dan etika peserta didik. Kondisi ini membuat prinsip belajar pada pendidikan khusus menganut prinsip belajar yang fleksibel/luwes baik dilihat dari segi waktu, materi dan penilaian (Musfirotun Yusuf, 1987: 31-32). 


\section{Simpulan}

Mencapai hasil belajar seperti yang diharapkan, para pendidik perlu merencanakan dan menerapkan strategi pembelajaran terbaik. Keberhasilan belajar dan mengajar bergantung pada faktor-faktor pendukung terjadinya pembelajaran yang efisien dan efektif. Dalam sekolah, khususnya bidang kurikulum atau pembelajaran dibagi dalam tiga tahapan, yaitu rencana pembelajaran, kegiatan atau pelaksanaan pembelajaran dan penilaian hasil belajar. Temuan dalam penelitian ini ada empat antara lain (1) perencanaan pembelajaran PAI bagi ABK dalam settingan inklusi (2) pelaksanaan pembelajaran PAI yang beragam strategi (3) Evaluasi hasil pemeblajaran PAI(4) Kendala yang dihadapi baik dalam perencanaan, pelaksanaan dan evaluasi pembelajaran PAI di sekolah inklusi. 
Farida

\section{Daftar Pustaka}

DEPAG RI, 2007. Pedoman Umum PAI Sekolah Umum dan Luar Biasa, MapelPAI SDLB, Jakarta.

Effendi, Muhammad. 2009. Pengantar Psikopedagogik Anak Berkelaianan, Jakarta: Sinar Grafika Offset.

Ekodjatmiko Sukarso dkk. 2001. Assesment Anak Berkebutuhan Khusus. Jakarta : Dirjen PSB.

Kasim Mailani, Anak Berkeutuhan Khusus, dalam http://melanikasim.wordpress.com, diakses pada 12 Januari 2019.

Muhammad, Jamila KA. 2008. Special Education For Special Children. Terj Edy Sembodo, Jakarta: Hikmah.

Tafsir, Ahamd. 2005. Ilmu Pendidikan Dalam Perspektif Islam. Bandung: Remaja Rosdakarya.

Yusuf, Musfirotun. 1987. KeragamanTeknik Evaluasi dan Metode Penerapan Jiwa Agama. Jakarta: IND-HILL-Co. 